\title{
Chapter Eight Revisiting Chapaev: Viktor Pelevin and Vasily Aksyonov
}

\begin{abstract}
Boys! Recall the famous story of the legendary character celebrated by Boris Polevoi!

Ребята! Вспомните знаменитую историю легендарного персонажа, воспетого Борисом Полевым!
\end{abstract}

-Viktor Pelevin ${ }^{1}$

But Chapaev was revisited, over and over. In this final chapter we come full circle. Despite Astafiev's indictment of traditional Soviet war literature, in the post-Soviet period the figure of Chapaev continued to resonate. As we have seen, he and his comrades, literary depictions of war heroes and Cold War antiheroes, were constants across the Soviet twentieth century.

Long after people ceased reading Furmanov's 1923 novel, Vasily Chapaev lived on. In 1941 he was mobilized to help with the war effort and featured in the short film Chapaev Is with Us! ${ }^{2}$ The Vasiliev brothers' film too remains beloved, although in post-Stalinist times more for its humor than for its historical portrayal of the Civil War era. ${ }^{3}$ Even in twenty-first-century Russia, Soviet-era Chapaev anecdotes still make up a significant percentage of all jokes told. History and humor. The appropriation of Chapaev by the Soviet and post-Soviet populace speaks to the centrality of the myth of the peasantwarrior and to the necessity of treating Soviet sacred myths with a grain, or a gorst (handful), of salt.

1 Viktor Pelevin, Omon Ra. Zhizn' nasekomykh. Zatvornik i Shestipalyi. Prints Gosplana (Moscow: Vagrius, 1999), 7-122; 28-29.

2 http://www.youtube.com/watch? $\mathrm{v}=\mathrm{UChik} 40 \mathrm{rcrw} \&$ feature=related. Also interesting is the "Hollywood-style" trailer created by recent fans to accompany the original film: http://www.youtube.com/watch?v=t-ORc8hQjR0\&feature=fvsr.

3 See Graham, Resonant Dissonance; Lilya Kaganovsky, How the Soviet Man was Unmade: Cultural Fantasy and Male Subjectivity under Stalin (Pittsburgh: University of Pittsburgh 2008); and John Haynes, New Soviet Man: Gender and Masculinity in Stalinist Soviet Cinema (Manchester: Manchester University Press, 2003) for discussions of Chapaev and Chapaev. Upon its release in 1934, the film was lauded by Pravda, whose editorial read, "The whole country is watching Chapaev!" Graham credits the surge of Chapaev jokes to the thirtieth anniversary of the film in 1964, after which it began to be shown frequently on television (Resonant Dissonance, 6). 
In this chapter we look at two writers who in the post-Soviet era came back to the figure of Chapaev in order to explore the definition of the military hero in a post-heroic, post-Soviet nation. Both Viktor Pelevin and Vasily Aksyonov returned to Chapaev and used him as a touchstone to help evaluate the legacy of the Soviet century and the Socialist realist hero, Pelevin in his novel Chapaev and Pustota and Aksyonov in his short story "The Ship of the World: Vasily Chapaev."

Socialist realist heroes were ripe for parody, and Pelevin has a field day with them in his 1991 Omon Ra. We'll open our analysis below with this novella. But if Astafiev demonstrated that even World War II could not produce heroes in the same way any more, Chapaev and the legacy of the Civil War were a virtual playground for writers. By the 1990s, the figure of the literary war hero as he was created in the 1920s was utterly inconceivable. Pelevin and Aksyonov could not even get angry about this loss as Astafiev did. For them, he was fodder for postmodern play.

\section{Exposing the Soviet Military Complex: Viktor Pelevin and Omon Ra}

When Viktor Pelevin won the Booker Prize in $1993,{ }^{5}$ the panel of judges recognized that he was among the most exciting figures in the contemporary post-Soviet literary world. Born in 1962, Pelevin grew up in the dark twilight of the Soviet Union, the son of a military instructor and a school teacher of English, and his fiction offered dystopian visions of the modern world. His early work tended to incorporate the experiences of youth culture: Western film and television, computer games, drug experimentation, advertising lingo. Though he differs in several ways from his older contemporary Vladimir Makanin-Pelevin dark, cynical, and amusing; Makanin more serious and brooding-he wound up locating one of his novels in the same place as Makanin's Underground: the madhouse.

Pelevin published the novella Omon $\mathrm{Ra}$ in 1991. The first-person narrative features a character who initially seems like a Soviet success story. The

4 Vasily Aksyonov, "Korabl' mira: Vasilii Chapaev," in Negativ polozhitel'nogo geroia (Moscow: Vagrius, 1996), 159-177. First published in Znamia no. 1 (1995).

5 Pelevin was honored with the Small Booker for his debut collection of stories, The Blue Lantern. He has won numerous prizes since and was named the Best Writer of 1996 by the journals OM and Ogonek. See O. Bogdanova, S. Kibal'nik and L. Safronova, Literaturnye strategii V. Pelevina (St. Petersburg: Petropolis, 2008), 114. Viktor Erofeev has supposedly stated that "in the post-Metropole generation [that is to say, his own and Vasily Aksyonov's generation-AKB], there is no generation, only Pelevin by himself" (Bogdanova et al, Literaturnye strategii, 6). 
young man is a virtual orphan, escaping his personal family (where his father is a drunk and his deceased mother a distant memory) to join the big Soviet family. Just like the boys of ' 24 , he enlists in the Soviet military, in this case an elite military academy where he hopes to be trained to be a part of the vaunted Soviet space program. He plans to fly to the moon. As we saw in Voinovich's song about the space race, if the Cold War can be said to have produced any real heroes, surely they were the cosmonauts who beat the United States into outer space.

The narrative is utterly conventional: told by Omon himself, who describes his childhood, schooling, and first job, occasionally falling into reminiscences as he interacts with the social structures and individuals whom he meets in his daily life.

That life-like the Soviet Union itself-turns out to be patently absurd, and this text is driven by a different heroic model. Not the Civil War peasant leader Chapaev, with his spontaneous energy and his love of horses and the elemental, but the Soviet war hero Alexei Maresiev. We discussed Polevoi's 1946 classic postwar socialist realist novella The Story of a Real Man by Boris Polevoi and its cinematic counterpart, Alexander Stolper's 1948 film of the same name, briefly in chapter 5. ${ }^{6}$ To reiterate, Maresiev was a famous World War II pilot who crashed his plane behind enemy lines and crawled back through the woods, broken legs and all, to eventually fly again as a double amputee. This, Polevoi had asserted, was a real man.

The institute where Omon has enrolled is dedicated to making "real men" out of its cadets. In other words, in a surreal and sadistic realization of Maresiev's path to heroic martyrdom, the boys all undergo an operation to simulate his fate. In this send-up of the macho military code, according to which boys become men through training and experience, the cadets are given a mechanized and surgical shortcut to heroism. However, our hero Omon, along with his friend Misha, is tapped for an even more elite program. Their instructor says, "There's time for you to become real men later," and puts off their double amputations. ${ }^{7}$

6 In an interview for Victory Day in 2001, the real Mares'ev claimed, "I'm a person, not a legend!" See Izgarshev, “Alexei Mares'ev: 'Ia chelovek, a ne legenda.”

7 Pelevin, Omon $R a, 32$. In the English translation this reads, "You have been registered immediately for the first-year course at the KGB secret space-training school-so you'll just have to wait a bit before you become Real Men. Meanwhile, get ready to go to Moscow." Omon Ra, trans. Andrew Bromfield (New York: New Directions, 1998), 36. 
Pelevin is not interested in providing a new path to martyrdom or even heroism in his fiction. Rather, he ridicules the symbols and discourses of Soviet life, pointing out that the Emperor is not wearing any clothes, that the Wizard is simply a man behind the curtain. In this novella he does so in an utterly flat, realistic narrative, with only the occasional philosophical aside or metaphorical image. For Pelevin, there is nothing sacred, except perhaps the individual consciousness. It is the only space left, perhaps, for heroic action.

In Omon $\mathrm{Ra}$ he lampoons the food, the summer camps, the poetry, even the military training of his homeland (focusing more on the jokes instructors tell than on any actual space aeronautics). Omon was named by his father for the Soviet special forces in the hopes that his future would be bright. But the reader questions that future when it emerges that even as a small child on the playground little Omon felt in his "soul a loathing for the state."

As it turns out, Omon is no Soviet hero. In Omon $R a$, Pelevin has conflated two episodes of Soviet history and the heroes that they produced-the heroes of World War II and the cosmonauts of the Cold War-and turned them into a macabre parody. Pelevin has collapsed history, thus denying Soviet history any motion or change.

Only in one small paragraph of the narrative does it seem like this parodic Soviet world of cosmonauts may all be a dream. The reader (and eventually the protagonist) becomes aware that Omon's "flight" is a fake, and his travel across the face of the moon turns out to be underground in an abandoned tunnel of the Moscow Metro system, something Pelevin, who studied to be a transportation engineer, would have known plenty about. Omon travels on a converted bicycle. When asked what he's thinking about during the journey, Omon responds reluctantly:

Well, I often remember my childhood [... . ] How I used to go riding on my bike. It was a lot like this. And to this day I don't understand it - there I was, riding along on my bike, with the handlebars down low, and it was really bright up ahead, and the wind was so fresh.... [...] I thought I was riding towards the canal. ... So how can it be that I. ...9

Perhaps in some "realistic" version of the narrative, this whole novella is a dream, and Omon himself has crashed his bicycle into the canal as a ten-year-

8 Omon $R a, 11 ; 8$ in the English translation.

9 Omon $R a$, English translation, 129; 102 in original. 
old and is spending the rest of his life in a semi-coma. But it is the components of the dream-the mockery of adults toward the "cadets," the yearning of the young men to accomplish something in their otherwise empty lives, their equal parts anticipation and dread at the thought of the feats they may be asked to achieve-that create the poignancy of this text, produced when "everything [...] was no more."

During late socialism, as Yurchak has argued, much of the force of Soviet authoritative language "came through rhythm, sound, and phraseology that looked and sounded impressive." ${ }^{10}$ Pelevin's Omon Ra demonstrates the emptiness of that rhetoric. ${ }^{11}$ Some critics have seen the entire story as deliberately surreal, and it is surely the irony-free presentation of the amputation ritual more than anything else that indicts both Soviet myths of heroism and Soviet official history itself. ${ }^{12}$

\section{Chapaev Rides Again - with a Madman for a Sidekick}

Four years after Omon Ra, Pelevin published Chapaev and Pustota and reached back even further in Soviet history to the ur-text of Soviet heroism. In fact, the title of Chapaev and Pustota connects the novel to other texts of Russian literary history, not only fitting the model of "this and that" (as in Fathers and Sons, Crime and Punishment, War and Peace) but, in its use of proper names, also repeating the model of Taras Bulba, Oblomov, Anna Karenina, among others. ${ }^{13}$ However, instead of the cheerful swashbuckling peasant we see, particularly in the Vasilievs' 1934 film Chapaev, in Pelevin's incarnation Chapaev is a tuxedo-wearing philosophical guru, much smarter and deeper than anyone around him. By the 1990s, the naif has become the sophisticate. In the novel, Furmanov and the entire Soviet political system are dismissed as if they had no historical relevance nor power.

10 Yurchak, Everything Was Forever, 78. Pelevin was a member of what he himself calls Generation $P$, that last Soviet generation about whom Yurchak writes.

11 Mark Lipovetsky writes about the "hyper-reality of Soviet simulacra [as] produced by Soviet ideology" and argues that in this first book both Pelevin and his protagonists were on a "quest for reality within the world of simulacra." Lipovetsky, "Russian Literary Postmodernism in the 1990s," Slavonic and East European Review 79.1 (January 2001): 47.

12 Lilya Kaganovsky believes that in this text Omon is given a "way out." See "How the Soviet Man Was (Un)made," Slavic Review 63.3 (Autumn 2004): 596.

13 We might add The Accursed and the Dead to this list of titles. For further analysis of the Buddhist logic inherent in the title, see Aleksandr Zakurenko, "Iskomaia pustota," Literaturnoe obozrenie 3: 269 (1998): 93-94. 
Like Makanin, whom we discussed in chapter 6, Pelevin chose to set his novel at a Moscow hospital for the insane in the 1990s. The narration switches back and forth between this "real" time and the delusional time of Pelevin's main hero, who believes that he is actually living in 1919-1920 as a somewhat unwilling participant in the Russian Civil War. In Chapaev and Pustota, the reader is unsure for roughly the first third of the novel where, and more importantly when, "reality" actually is-revolutionary and Civil War Russia in 1919 or the post-Soviet insane asylum. Thus the historical context and time itself are from the outset doubled in the novel, which is built around the hero, Peter Pustota. In his own mind Pustota is a modernist poet turned Civil War commissar, although in 1990s "reality" he is a delusional young man in his mid-twenties undergoing psychiatric treatment.

The rest of the cast of characters is a rather humorous lot as well, drawn from the types of contemporary life and the pages of military history: the psychiatrist, Dr. Timur Timurovich Kanashnikov, whose name rhymes with the Kalashnikov rifle; the four patients who are the subjects for his dissertation research (Peter, "Simply Maria" - who takes his name from the eponymous Mexican television serial, Serdiuk, and Volodin); a new version of the Civil War commander Chapaev; and Baron Yungern, whose name is both a play on Karl Jung and a fictionalization of the historical Baron Roman von Ungern-Sternberg, a World War I hero who fought for the White Army during the Civil War. ${ }^{14}$ This postmodern narrative is consciously non-linear, folding back upon itself across time and space, though the main settings are the psychiatric hospital and the various landscapes of Civil War Russia, from Moscow streets, nightclubs, and apartment houses to the provincial manor home and estate commandeered by Chapaev's detachment.

The hero's name, Peter Pustota, has a rich and ambiguous significance, which gets lost in translation: pustota means "emptiness." ${ }^{15}$ Though the hero does to some extent act as an empty vessel into which others (his psychiatrist, fellow members of his group therapy, Chapaev, etc.) pour content, this explanation oversimplifies his character, which might benefit rather from

14 Baron Ungern, like Pelevin's fictional creation, was famed for his interest in Buddhism. Ungern fought against the Reds in Siberia and then in Mongolia during the Civil War.

15 In my discussion, I will call the hero "Pustota." Andrew Bromfield solves the punning problem in English by making him "Pyotr Voyd" in his translation of the novel. 
being viewed through the lens of "secular kenosis." ${ }^{16}$ Peter also embodies the solipsistic existence of the paradigmatic modernist poet, whom Pelevin lampoons in this pseudo-historical novel. Finally, the hero's surname of "emptiness" announces the philosophical underpinnings of the novel, as Pelevin and his narrator propose a self-absorbed variant of Buddhism in answer to late-twentieth-century Russian social problems.

Buddhism and religion take the place of politics, science, and medicine in Pelevin's hierarchy of values. It is no accident that the good doctor Kanashnikov in Pelevin's Chapaev and Pustota is writing his dissertation on the split personality. Here we have an historical allusion-his name also recalls the Kanatchikova dacha, one of the most famous insane asylums in Russia-within another important historical allusion, neither of which Pelevin really takes seriously. We discussed in chapter 6 how the definition of schizophrenia has been deeply significant in the history of Soviet psychiatric practice. ${ }^{17}$ Fittingly, Pustota's doctor-who is experimenting with therapies and treatments-slaps this diagnosis on the main character and his fellow patients and gives them the status of guinea pigs in a post-Soviet medical laboratory where the rights of the individual are no more respected than they were during the age of Brezhnev.

Again like Makanin, Pelevin draws freely from literary and cultural traditions of madness, not distinguishing particularly between the paradigms of refuge and torture when concocting his postmodern melange of references. Pustota explores the Menippean promises of madness without ever quite fully realizing them. For the patients, Pelevin's psychiatric ward is both a refuge from the insanity of newly capitalist Moscow and a door to other, transcendent worlds, and for Pustota this refuge and escape offers more excitement and intellectual stimulation than anything in Moscow on the "outside."

Peter Pustota understands that the madhouse is like any other repressive system: right away he notices the willingness of the other patients to participate in their various therapies and concludes that "the atmosphere of a madhouse obviously must instill submissiveness" (Chapaev i Pustota, 105). Pustota and his ward mates find themselves traveling in time and space as their dream therapy takes them into imaginary landscapes. The fact that these imaginary landscapes are primarily violent and militaristic - from Pustota's Civil War battles to mafia razborki to futuristic Hollywood film narratives featuring Arnold

16 See Wieda, "Secular Kenosis."

17 For a detailed description of the history of Soviet theories of schizophrenia, see Miller, "Theory and Practice of Psychiatry in the Soviet Union," 16. 
Schwarzenegger-ties the repressive atmosphere of the mental hospital to a post-Soviet society still struggling with the after-effects of a century of war. ${ }^{18}$

\section{Emptiness, Pelevin-Style ${ }^{19}$}

By collapsing 1919 into the 1990s, Pelevin links the beginnings of both of these new eras with a profound sense of emptiness. He explores the persona of his "empty" hero both through interactions with the characters from the Soviet "Chapaev text"-including Anka the machine gunner, but casting Peter as a smarter version of Chapaev's traditionally dense adjutant, Petya-and through psychotherapy. In the madhouse, Dr. Kanashnikov's group therapy sessions give the patients the opportunity to interact with each other's delusions and fantasies. The sessions-which have links to real Soviet psychiatric practice-involve collective hypnotic dreaming. ${ }^{20}$ As the doctor explains the therapy to his patient Pustota:

When the session comes to an end, a reaction sets in as the participants withdraw from the state that they have been experiencing as reality ...

18 On the connections between Chapaev and Pustota and Master and Margarita, see Bogdanova et al, Literaturnye strategii, especially 45-64.

19 For Russian criticism on Pelevin and this novel, see Pavel Basinskii, "Iz zhizni otechestvennykh kaktusov," Literaturnaia gazeta 22: 5604 (29 May 1996): 4; Dmitrii Bykov, "Pobeg v Mongoliiu," Literaturnaia gazeta 22: 5604 (29 May 1996): 4; Andrei Nemzer, "Kak ia upustil kar'eru" (May 1996), reprinted in Literaturnoe segodnia, 313-315; Irina Rodnianskaia, “I k nei bezumnaia liubov'," in Novyi mir 9 (1996): 857; 212-216; Karen Stepanian, "Realizm kak spasenie ot snov," Znamia 11 (1996): 194-200; Zakurenko, "Iskomaia pustota." See also the admiring profile by Jason Cowley, "Gogol à Go-Go," New York Times Magazine (23 January 2000): 20-23; Alexander Genis, "Borders and Metamorphoses: Viktor Pelevin in the Context of Post-Soviet Literature," in Mikhail Epstein, Alexander Genis and Slobodanka Vladiv-Glover, Russian Postmodernism: New Perspectives on Post-Soviet Culture (New York: Berghahn Books, 1999), 212-224; and Marina Kanevskaia, "Istoriia i mif v postmodernistskom russkom romane," Izvestiia AN, seriia Literatury i iazyka, 59.2 (2000): 37-37. Gerald McCausland looks at Chapaev and Emptiness in the context of Pelevin's other work in his "Viktor Pelevin and the End of Sots-Art," in Endquote: Sots-Art Literature and Soviet Grand Style, ed. by Marina Balina, Nancy Condee, and Evgeny Dobrenko (Evanston: Northwestern University Press, 2000), 225-237.

20 According to Miller, the favorite modes of psychotherapy in the Soviet Union were "hypnosis, 'culture-therapy' (using art, music, etc.), and work therapy" (Miller, “Theory and Practice of Psychiatry," 17). In Chapaev and Pustota we see examples of both hypnosis and "culture therapy." Miller goes on to state that in Soviet psychiatry "there is an assumption ... that psychotherapy is a process in which the patient overcomes his disorder through a realization of the facets of the disorder," a description that matches closely the theories of Kanashnikov. 
your ideas and your mood might infect the others taking part in the session for a certain time, but as soon as the session comes to an end, they return to their own manic obsessions, leaving you isolated. And at that moment-provided the pathological psychic material has been driven up to the surface by the process of catharsis-the patient can become aware of the arbitrary subjectivity of his own morbid notions and can cease to identify with them. (Chapaev i Pustota, 38)

In the novel, Dr. Kanashnikov's group therapy and the madhouse itselfwith all its odd characters-play and experiment with the idea of individual identity.

As we have discussed, questions of the self and the collective were key to Soviet discourse and have become even more charged in post-Soviet times both within and outside fiction. As Russia struggled-and still does-to understand what form of government and civil society will be its next incarnation, self and society have become central to the novel as well. In a postcollective society, what is the meaning and role of the individual? What is a split personality, and what is a whole personality? If in fact there is anything wrong, how can healing take place? Who, in the end, is the hero, and in what social context is he created? The therapies that go on in the madhouse are a metaphor for the struggle to determine exactly what the nature of individuality will be in this new post-Soviet society. ${ }^{21}$

Kanashnikov's psychotherapy raises these questions for the four patients in his post-Soviet madhouse, as well as for those on the outside, since the patients represent four types of post-Soviet citizen-the philosophical loner who imagines he's a poet (Peter), the young (and "Westernized") homosexual who has fallen under the influence of Mexican soap opera and American film culture (Maria), the unemployed alcoholic who has raised drinking to an almost metaphysical level (Serdiuk), and the mafia boss who experiments with psychedelic drugs (Volodin). ${ }^{22}$

21 In Pelevin, as might be expected, the madhouse is only a metaphor, unlike in Makanin where the narrative's irony does not preclude a portrayal of real suffering.

22 Several Russian critics have identified these patients as representatives of contemporary Russian types. For example, Rodnianskaia calls the patients "four modes of the 'Russian soul': the man of the people, the bum/dreamer [mechtatel'nyi bosiak], the 'New Russian' and, of course, the Russian intellectual with his 'split false personality' and his call to free ourselves from 'so-called inner life"' (Rodnianskaia, "I k nei," 214). Nemzer argues that the illnesses of Petr's three fellow patients are "built on the stereotypes of contemporary mass culture" ("Kak ia upustil kar'eru," 314). 
Pelevin's novel has a higher aim than mere imaginative representation of reality. Peter Pustota experiences his 1919 self as his true self, and the scenes in the lunatic asylum as "nightmares." But even within what he sees as his true self, he is engaged with the idea of the individual, the "I," and how he interacts with community and society. As a modernist poet, he titled one of his books of poetry The Kingdom of I, and he explains, "I used to do a lot of traveling, and then at some moment I suddenly realized that no matter where I might go, in reality I can do no more than move within a single space, and that space is myself" (Chapaev i Pustota, 282). So for the protagonist, the entire world has collapsed into himself; he is his very own kingdom.

In a political sense, after the 1917 Revolution the kingdom actually did disappear, leaving individuals to seek new direction for their lives. And in a literary sense, Peter Pustota would not have been the only modernist poet to find all meaning within himself. For post-Soviet times, the situation is remarkably similar: the Union has dissolved, and the poet seeks meaning in the fragments of history that constitute his own essence. Post-Soviet solipcism is isolating, to say the least.

Both Peter and Pelevin would say the novel takes place "nowhere" (nigde): within the head of the individual and therefore outside of time and space. Indeed, Pelevin himself has punned that "this is the first novel in world literature whose action takes place in absolute emptiness." ${ }^{23}$ Kanashnikov's psychiatric notes state that Pustota "does not find placement in a psychiatric hospital oppressive, since he is confident that his 'self-development' will proceed by 'the right path' no matter where he lives" (Chapaev i Pustota, 104). In his travels with Baron Yungern, who is a kind of metaphysical guide, ${ }^{24}$ Peter comes to understand that "I myself ... constitute the only possibility of being, the exclusive means by which all these psychiatric clinics and civil wars came into the world" (Chapaev i Pustota, 220).

The pseudo-Buddhist Yungern explains to Peter that he should strive to reach that "nowhere," which is a place of "eternal freedom and happiness":

23 See Sally Laird, "Viktor Pelevin," Voices of Russian Literature (Oxford: Oxford University Press, 1999), 181. Rodnianskaia has argued that the novel takes place both in post-revolutionary and post-Soviet times, and that "these two epochs 'rhyme"' (Rodnianskaia, "I k nei," 214), while Stepanian contends that "the entire narrative follows the stylistics of a dream" (Stepanian, "Realizm kak spasenie ot snov," 195).

24 Yungern officially "heads up one of the branches of the afterlife"; Zakurenko characterizes him as a "contemporary colleague of Woland's" (Zakurenko, "Iskomaia pustota," 94). 
"Why should you ... not find yourself in this 'nowhere' while you are still alive? . . No doubt you are fond of metaphors-you could compare this to discharging yourself from the mental home." Chapaev, resurrected as a tuxedo-wearing guru who in the Civil War scenes is both Peter's military commander and his philosophical mentor, also advises his disciple to discharge himself from the hospital (Chapaev i Pustota, 223, 270).

Pelevin rejects the madhouse as a place of medical practice, lampooning psychiatric techniques such as drug therapies, hypnosis, and group sessions. In the world(s) of Chapaev and Pustota, madness takes on a complete subjectivity, with all objective scientific discourse evaporating.

One thing that does go on in the clinic is joke telling. Near the end of the novel, the patients in the mental hospital participate in this popular culture ritual, retelling Chapaev jokes-and the patient Peter Pustota "corrects" them, explaining the "real event" behind each anecdote. Like Dovlatov, with the back stories of his Soviet journalistic feuilletons, and other writers we've looked at, Pelevin is exploring issues of fact and myth. But here the facts are part of a patient's delusion, and the myths are the beloved popular culture jokes that poked fun at the heroic figure of Chapaev in the first place. The patient stands in for Soviet citizens as a whole, who somehow needed to believe in those facts about Soviet wars and Soviet heroes.

Unexpectedly, in an almost surreal scene, the doctor gives in to the hero's desire to check himself out of the asylum and facilitates the exit of the post-revolutionary poet into contemporary Moscow. The novel ends with our hero Peter leaving the hospital, which has been his home for over three hundred pages, underscoring yet another joke-that nothing gets cured in the clinic.

\section{No Way Out}

Thus Chapaev and Pustota ends where it began, almost as if the intervening Soviet years between 1919 and 1991 had no significance. After Peter has let himself out of the institution, he returns to downtown Moscow. The narrative repeats word for word the opening paragraphs of the novel:

Tverskoy Boulevard appeared exactly as it had been when I last saw it-once again it was February, with snowdrifts everywhere and that peculiar gloom which somehow manages to infiltrate the very daylight. The same old women were perched motionless on the benches, 
watching over brightly dressed children engaged in protracted warfare among the snowdrifts; above them, beyond the black latticework of the wires, the sky hung down close to the earth as though it were trying to touch it. Some things, however, were different ... (Chapaev i Pustota, 323-324)

In the very first scene of the novel-which takes place in early 1919-the narrator noticed that the statue of Pushkin on Tverskoy Boulevard looked different than it had two years previously when he had last seen it. Pushkin now seemed a little sad because he was wearing a red banner proclaiming, "Long live the first anniversary of the Revolution." At the end of the novel Peter comments that "the bronze Pushkin had disappeared, but the gaping void that had appeared where he used to stand somehow seemed like the best of all possible monuments."

In actual historical Moscow, of course, the Soviets moved the Pushkin statue across the street, so that when Peter looks at the space where he expects the statue to stand, he finds only an empty square. Pustota continues to survey his surroundings: "Where the Strastnoy Monastery had been, there was now an empty space [pustota], with a sparse scattering of consumptive trees and tasteless street lamps" (Chapaev i Pustota, 324). In the meantime, too, between Peter's two realities, Tverskoy Boulevard had been called Gorky Street from 1935 to 1990. Tverskoy also came full circle.

Pelevin uses the historical circumstance of Pushkin's peregrination to create a metaphor of post-Revolutionary and post-Soviet Russia: in Pustota's imagination, in 1919 Pushkin was Bolshevized and forced to wear a revolutionary banner, and Pustota himself left the spent field of decadent poetry for the battlefields of the Civil War. In "real" 1990s Moscow, the statue of Pushkin has been replaced by emptiness, or void, and the abiding Russian hero, Pushkin, makes way for the banal and delusional Peter. With the monastery gone as well, Peter finds himself without direction, and wryly quotes Dostoevsky's Marmeladov: "And have you any idea what it is like, my dear sir, when you have nowhere left to go?"

Pelevin's hero encapsulates the fate of the individual under the Soviets: in post-revolutionary Russia, the hero was forced into the collective, but in the postmodern world, without any meaningful collective, the hero is absent, an emptiness in and of himself. This novel with its circular narrative brings to mind Alexander Blok's 1912 poem: 
Night, a street, a lamp, a chemist's shop,

A meaningless and dim light.

Even if you live for another quarter of a century,

Everything will be like this. There is no way out. ${ }^{25}$

In his own "no way out," which reads as a pseudo-Buddhist turn, Peter chooses to retreat within that emptiness, into a solipsistic state, which Pelevin names with a geographic pun: "Inner Mongolia." ${ }^{26}$

For Pelevin the madhouse serves as a stage upon which to explore the notion of how to define one's individuality, but in his work he also explores the time-tested tropes of Soviet fiction, including the trope of Vasily Ivanovich Chapaev, war hero and socialist realist icon. The business of war, particularly the Civil War and World War II, is a serious one, but in a culture like Russia's, where the official became bureaucratized and anything state-sponsored was ripe for underground parody, these wars too presented material for satire.

As a historical and cultural figure, Chapaev bridges the gap between the serious realist presentation of the experience of the hero in wartime and the anekdot-alized parody of that high-flown portrait. These two strands of Soviet literature, both with a version of war hero at their center, include such opposite texts as Solzhenitsyn's One Day in the Life of Ivan Denisovich and Dovlatov's The Zone and The Compromise. Though opposite sides of the coin, they encourage their readers to question "history," to approach both the past and the present with a critical eye-a necessary corrective after decades of belief in the "appearance" of truth.

\section{The Feast of the Soul: "Pir dukha"}

Reconsidering and reshaping the Chapaev myth and other Soviet myths has been part of a larger trend of post-Soviet life. Confronting the heritage of war and its symbols, authors have used characters like Chapaev and Stalin, what a recent Russian critic called "branded historical figures" ("brendovye

25 Blok's "no way out" explored the rash of suicides in his time, and in that sense Pelevin is more optimistic. See D. S. Likhachev, "Iz kommentariia k stikhotvoreniiu A. Bloka 'Noch', ulitsa, fonar', apteka,' Russkaia literatura 1 (1978), 186-188.

This is what made the novel controversial in Russia: if the pseudo-Buddhist message of this and some of Pelevin's other works really is "check out of reality, find your own Inner Mongolia," just as Gus Van Sant's characters dreamed of doing in the 1991 American film My Own Private Idaho, then certainly Pelevin is an antiprophet for the new Russia, a writer promoting the further disengagement of already disaffected youth. 
istoricheskie figury"), ${ }^{27}$ to engage the past while also selling books. The term "branding," along with "business," "marketing," and many other new vocabulary words, came to Russia from the commercialized and capitalist West, and these terms participate in a discourse that takes history and turns it into a commodity. In the literary world, contemporary writers in Russia are taking a page from Umberto Eco (and hoping for the monetary success that comes from Hollywood films like his The Name of the Rose): they want to maintain a highbrow profile while also selling enough books to become famous. ${ }^{28}$

This is the context in which Vasily Aksyonov (1932-2009) published his short post-Socialist, postmodern tale "The Ship of the World: Vasily Chapaev" (1995). ${ }^{29}$ In this entertaining story, Aksyonov explodes some of the same Soviet and post-Soviet myths and stereotypes that Pelevin tackles (including Chapaev, socialism, the Komsomol, mafia razborki, and new age religion). Also like Pelevin, and like Chapaev, his narrative features two important tropes of Soviet Russian literature: a river as central to the topos of the story and a hero who in the end saves the day.

Aksyonov uses his story to draw implicit parallels between the beliefs and practices of Communist ideology, business, and religious cults. He also valorizes his inventive and essentially honorable-if perhaps also drunken, lassitudinous, and lustful-young hero, the guide and translator Lev. We see here a late-twentieth-century version of Dovlatov's antihero. Not surprising, since Aksyonov was one of the writers Dovlatov read as a young man.

The title of the story could also translate as "The Ship of Peace," which might fit better the Hare Krishna passengers on board, but given that the text is very much about attempts to bridge cultural differences, "Ship of the World" works as well. Certainly Aksyonov was exploiting the dual meaning of "mir," and he may also have been referring to the "Ship of Fools" concept, related both to madness and to philosophers, especially in the context of exile from one's homeland (cf. the 1922 "ship of philosophers," intellectuals expelled from Soviet Russia much as Aksyonov and many of his generation were half a century later).

Aksyonov's text illustrates some important points about post-1991 relations between Russians and foreigners and about contemporary uses of history and heritage in post-Soviet Russia. Thus not only does Aksyonov write

27 Vladimir Elistratov, "Filosofiia mifokitcha," Znamia 5 (2006).

28 This is a paraphrase of Elistratov's argument.

29 V. Aksyonov, "Korabl' mira: Vasilii Chapaev." 
about the confrontation of culture and commodity, as we'll explore below; as a Russian American fiction writer, his work also exemplifies that clash. ${ }^{30}$

Aksyonov engages the West in this narrative by using a collection of Australians in search of a spiritual experience, thus creating the effect of estrangement: these non-Russian characters perceive Russia and Chapaev using utterly "other" parameters. They hear Russian words and names that "sound like" their own foreign vocabulary. Their only other route to Russian culture is via their assigned translator, who tries to present them with the historical Chapaev and his place in Russian history and culture and to shape that information into a satisfactory customer service experience as offered by his firm, the touring agency Wandering Soul.

In the story, Aksyonov overlays contemporary clichés on top of deep Soviet symbols of war and heroism, from revolutionary figures to their socialist realist permutations, to the trauma of World War II that resonates with the trauma of Soviet communism and totalitarian rule. The plot concerns the arrival in Russia of a Hare Krishna sect led by a former dental prosthetist from Australia. Derek Door, who took the name Swami Shrila Prabhavishnu, brings a group of followers from the so-called Ashram of the Four-Armed One to Russia. Their goal is "to irrigate the earth with the eternally refreshing chants of Hare-Rama” ("Korabl' mira," 160, 161).

The narrative presents the Australians' quest as an utterly plausible effort, made possible by the fall of the Soviet Union and the resulting freedom for alternative religious groups. Indeed, it is utterly plausible: the twin lure of Mother Russia with her attendant "Russian soul" (part of an old pilgrimage tradition that we can trace at least as far back as Tolstoyans crossing the ocean to catch a glimpse of the master) and the sudden economic and political accessibility of Russia, after decades of restricted travel, has brought hordes of tourists, curiosity seekers, culture mavens, history buffs, and evangelical missionaries of all stripes to the Russian Federation since 1991.

These particular travelers have chosen the Volga River, symbol of Mother Russia and the longest river in Europe, for their cruise, and they plan to

30 Russian commentators have over the years emphasized Aksyonov's status as a "feelgood" writer. In the words of Evgenii Popov, before his emigration Aksyonov "radiated fun, swagger, victory by his very life and image." But even after his emigration, in the words of another critic, Aksyonov "remained a truly Soviet writer." See Popov, "Dve liubvi: Aksyonov i Dovlatov," Vsemirnoe slovo 9 (1995): 12-13: 12 and Evgenii Ponomarev, “Sotsrealizm karnaval'nyi," Zvezda 4 (2001): 213-219: 216. 
cleanse the waters of the "miasma of collapsed Communism" and facilitate the "renaissance of the shores" ("Korabl' mira," 161) —an inverted baptism of the vital waterway and its adjacent lands. Like the fiction of the 1970s, Aksyonov's story uses irony to chronicle the relationship between the central protagonist and his surroundings. Inverting the war-hero relationship, the action of the story takes place in the wake of Soviet "defeat," and the hero has been reduced to giving tours of that defeat to some of the westerners who have "won" the Cold War.

Aboard a rusty steamer called Vasily Chapaev, Prabhavishnu and his shaven-headed, saffron-robed followers set off on the Volga in the direction of Samara. ${ }^{31}$ Their guide and translator, Lev Obnag, at first holds himself aloof from the cult members but, as part of his duties, translates their speeches to the surprised sailors of other passing crafts, ending each with a heartfelt "HareRama!" As the steamer floats along the river, the naïve, happy "bhagavats" dance and chant. The contrast with post-Soviet life is stark; as the narrator puts it in one instance, "The gloomy industry of exhausted socialism watched from the banks as the crowd entered into ecstasy" ("Korabl' mira," 163). The river, a symbol of travel and communication, brings the foreign tourists/cult members into a somewhat distant contact with the ordinary post-Soviet life on its banks.

The central figure in the narrative is the Russian translator Lev, who is described as a Muscovite, a graduate of the Maurice Thorez ${ }^{32}$ Institute of Foreign Languages, "as worldly-wise and tattered" as the steamer itself. His appetites know no measure; indeed, the reader is told, "He had grown a belly of a size rather surprising in a man of 28 years."

It could be stuffed into his jeans only with difficulty and could not be sucked in beneath his ribs when girls were approaching. His patchy beard and ringlets of hair-which resisted a comb-left little of his face on view; you could just glimpse his nose, the pillows of his cheeks, or his eyes, shining with a lazy cynicism, sometimes the left eye, sometimes the right, depending on which way his hand was pointing at the given moment. ("Korabl' mira," 163)

31 For the Swami, the name Samara is evocative of the words "Samvara," or "highest good" as well as "Samantabhadra," which signifies the entirely good power that moves the universe, and reminds him of the "Samaritans," those "bearers of peace and love" (Aksyonov, "Korabl' mira," 161).

32 Maurice Thorez (1900-1964), the leader of the French Communist Party, had ties both to Stalin and the Comintern. 
His physique is anything but heroic and instead borders on the grotesque. Lev is a highly unlikely hero, but one whose role as cultural interpreter places him as mediator between the tourists and his fellow Russians.

The foreign passengers are shocked at the unclean Lev, whose habits of eating meat and drinking alcoholic beverages violate both the body and the mind, and they assume that proximity to them will make the sinner want to imitate their ways. Lev in turn finds the diet of the cult-mostly nuts and other foods that can be harvested without "pain" to the tree-horrific. "These schizos have created for themselves a voluntary gulag, if you don't take into account the ritual fucking," thinks Lev ("Korabl' mira," 164). The foreigners' reaction to Lev highlights their own righteousness and symbolizes a widespread attitude of the West toward Russia: "Once Russians see the light, they will emulate us and believe in our gods and our markets!"

The irony here is lost on the deliberately self-abnegating Australians: Russians were forced to endure hardships and deprivations that the Australians simply could not imagine. They suffered through the complications of the Civil War, starved and froze through the deprivations of the Second World War period, and lived in and through a real Gulag. Finally free of those historical circumstances, their country has become a playground for foreigners. And here the Australians have come to Russia to play at hardship.

But as a post-Soviet citizen, Lev evaluates the Krishnaites' code of behavior using his own cultural parameters; in the post-Socialist explosion of possibilities that enables him to make his living with Wandering Soul, selflimitations do not seem to him desirable. As Konstantin Kustanovich has argued, Soviet culture was maimed precisely by the curtailment of freedom, and not only in prison camps: "Deprived not only of political freedom, but also of the freedom to choose a job or a place of habitation (because of the infamous propiska laws), the freedom to possess property, and the freedom to conduct business, the Soviet people had only two freedoms left: drinking and sex." 33

Lev, when the opportunity arises, indulges in both-as frequently as possible. Aksyonov, for his part, indulges in another favorite Russian pastime: punning. Lev's speaking name gives him the chance when Lev decides he'd like to take part in the "morning ritual of universal union," the "ritual fuck-

33 K. Kustanovich, "Erotic Glasnost," 138. Joseph Brodsky put it somewhat differently, arguing that in the Soviet period, the free enterprise was limited to "adultery, moviegoing, Art" ("Less than One," 22). 
ing": the "bhagavats undressed Obnag to the skin," ${ }^{34}$ a sentence that offers wonderful internal rhymes and repetitions. From this point in the narrative on, Lev maintains a more pure lifestyle while with his charges, although he continues to drink beer and vodka and indulge in meat products while alone in his cabin. Is he becoming more naked, more pure, in falling under the influence of his Western charges, or is he merely fulfilling his role as a mediator and translator of language, history, and culture?

It is Lev's purpose to prevent mistranslation of Russian and Soviet culture. Generally, the swami and Lev speak past one another, each with his own agenda. For example, the swami asks, "After whom is our boat named, Lev? I sense an echo of the eighteenth main purana."

"Not surprising," Lev answers immediately. "Vasily Chapaev is an historical hero and at the same time the source of good moods." Lev has given a perfect definition of the meaning of Chapaev; these two aspects have defined his role in Soviet culture since the 1920s.

The joking image is perhaps more contoured and significant than the ideological symbol itself. The tourist boat on which Lev works represents the fame of Chapaev and the simultaneous neglect of that fame. The fact that the socialist realist heritage industry could appropriate the naming rights of this branded historical figure and put that name on a rusting hulk-or put that name on a tourist steamer, which is subsequently permitted to fall into decay and become a rusting hulk-adds yet another dimension to the tradition of Chapaev jokes. Predictably, the story will end happily-Aksyonov's stories usually do-and in the end the simultaneity of Soviet ideology, "live" postSoviet culture, and the exploitation of heritage will all come together. ${ }^{35}$

Knowing the peace-loving nature of his charges, Lev deliberately avoids mentioning the violence inherent in Chapaev's service to his nation. As the steamer continues to sail, Aksyonov's post-Soviet readers, recalling our favorite Chapaev jokes, might still have in mind the tragedy of the Civil Waror indeed the travesty of what socialist realism and government intervention meant for Russian literature in the Soviet era-but the Krishnaites, the outsiders, have none of that context.

Lev does not try to present the complexity of Chapaev's image to the swami and his naive followers, nor perhaps does he initially understand it

34 "Bkhagavaty razdeli Obnaga donaga." "Korabl' mira," 165.

35 Ponomarev writes about Aksyonov in almost offended tones, claiming that his heroes are always happy and always win the day ("Sotsrealizm karnaval'nyi," 215). 
himself. In response to Lev's description, "the Bhagavats beamed with joy. To sail on a ship bearing the name of a hero who is also the source of good moods-what a blessing, what good luck!" ("Korabl' mira," 163). Nor does Lev explain the complexities with which the very term "hero" is invested in the Soviet and now post-Soviet context.

The ship sails on to Samara, which turns out to be a historically important tourist destination on a number of levels: it features the Soviet Chapaev industry as well as several significant World War II sites, and it is the home of the oldest Russian beer factory, Zhigulyovskoe (which, alas, Lev does not manage to visit, given the teetotaling nature of this particular group of tourists). ${ }^{36}$

In Samara, things get serious. The tourist fantasy is transformed into a confrontation with history. The "epicenter" of the story, ${ }^{37}$ according to the otherwise fairly unobtrusive narrator, is the central square of the ancient city of Samara. ${ }^{38}$ On that square-arranged around a sculptural group representing Chapaev and his fellow soldiers-stand four buildings:

The theater building, a Russian cake-like building of stone, from the end of the nineteenth century ... the Museum of Weaponry, in a formerly luxurious private home in the modernist style ... the tall, constructivist dildo of the Volga-Ural Military Region Headquarters ... and the large square building in the Soviet-Communist Party style poised atop the thirty-seven meter tunnel to the cave of the beast, Joseph Stalin. (“Korabl' mira," 167)

Samara, then known as Kuibyshev, was the location to which the Soviet government was to evacuate if necessary during the Second World War; and Stalin's bunker-twice the size and depth of Hitler's famous bunker, though

36 The narrative mentions the hundred-year-old beer factory in one breath with "underground weapons factories" (Aksyonov, "Korabl' mira," 166).

37 The first meaning of "epicenter" is geological, a point, directly above the true center of disturbance, from which the shock waves of an earthquake apparently radiate. The designation of the Samara square in this way invests the monument to Chapaev and the buildings surrounding it with the power to mark a cataclysm. The "cave of the beast" below may very well indict Stalin as the cause of the Soviet cataclysm.

38 One post-Soviet description of Samara calls it an "industrial, provincial city, that is to say calm and kind [...] Samara is known for its modernist architecture and its very decent dramatic theater. And also for the constant efforts of certain of its citizens to throw off the calm and complacency of everyday life." Galina Ermoshina, "Molodoi chelovek iz intelligentnoi sem'i," Review of Performance (2000). Ermoshina also quotes Boris Svoiskii as stating, "I think that real Samaravites must seem strange to people of strong nerves and principles. Frivolous. They hold nothing sacred." 
never actually used by Stalin-was only discovered and turned into a museum in the 1990s. ${ }^{39}$

This square, with its buildings ranging from the 1880s through the midtwentieth century, memorializes the military twentieth century. Chapaev Square represents the crossroads of Soviet life: the theater and the sculptural group are surrounded by the military and the Communist Party, and all turn toward the institutional repository of power, history, and heritage-the $\mathrm{Mu}$ seum of Weaponry.

And beneath it all, the "cave of the beast," the fantastic and secret bunker that was to secure the life of the "father of the peoples" in case of military disaster. The "constructivist dildo," sexualized by Aksyonov's narrative, is mirrored by the bunker's shaft below ground, and this vertical axis contrasts with the horizontal axis of the riverbank. For Aksyonov, the historical landscape presented by this ensemble of buildings encircling the Chapaev monument, along with the square's underground secret, offers a perfect toponymic setting for exploring history and heritage..$^{40}$ Aksyonov didn't have to invent a place to parody; Samara exists in all its multilayered history. He only tinkers with the cityscape by populating it with his characters.

As Lev launches into his tour-guide spiel about the history of Samara during the Second World War, his linguistic faculties begin to falter for the first time. The swami reacts strongly to the sound of "Kuibyshev," and Lev assumes he is reacting to the Russian three-letter word with which its first syllable rhymes (khui, or cock), but there is some other meaning that throws the bhagavats into a frenzy of dancing. "I feel that a storm is approaching, the Swami muttered. I don't like this! Kuibyshev has a bad sound to it! Pray, so that it does not hear us! Go away! Go away!"

This ridiculous scene distills the way Russians in the post-Soviet period struggled to come to terms with the Soviet past in general and with World War II in particular. At this epicenter of the story, what was taken as sacred

39 The Wikipedia entry on Samara includes the following, with no citation: "The life of Samara's citizens has always been intrinsically linked to the Volga river, which has not only served as the main commercial thoroughfare of Russia throughout several centuries, but also has great visual appeal. Samara's river-front is one of the favorite recreation places for local citizens and tourists. After the Soviet novelist Vasily Aksyonov visited Samara, he remarked: 'I am not sure where in the West one can find such a long and beautiful embankment. Possibly only around Lake Geneva."'

40 A review of Aksyonov's novel Moskva-kva-kva congratulates him on creating his own genre, "lyrico-ironic retromyth/kitsch," based on his use of Moscow streetscapes and toponyms in that work. See Elistratov, "Filosofiia mifokitcha." 
almost instantly becomes foreboding, and the swami begins to chant for it all to "go away."

Lev distracts the bhagavats with explanations and directs them to the center of the square. The sculptural group is described thus, beginning with Lev's tour-guide diction and continuing with the narrator's voice:

Splendid metallurgy, cast in bronze. The sculpture consisted of seven human figures and one horse. On horseback sat a man with a saber, behind him a sailor dragged a machine gun, a combat woman clutched a rifle, a Cossack bared his blade, a proletarian prepared a hand grenade, a country peasant also raised something or other in threat ... Also there was a man unmarked by social rank who had an enemy bullet in him and was preparing to fall. All the faces of this sculpture were filled with uncontrollable hatred. ("Korabl' mira," 168)

Instead of greeting the monument to Vasily Chapaev with cheerful animation, the group reacts with horror, and "a mute scene ensued, or even a kind of alternative sculptural group, where the Manizer bronze was counterbalanced by the devotees' folds of orange cloth and heads shaven to the shininess of a billiard-ball" ("Korabl' mira," 169). The two frozen-action scenes mirror each other, as the Krishnaites come into contact with the Soviet myth of the Civil War. Chapaev, the swami shouts, is no ship of the world-or of peace, for that matter-but rather an incarnation of the demon.

The official Sovietized square is sterile, empty, but the post-Soviet people's reaction to that space recalls Bakhtin's argument about the regenerative folk laughter of the public square. The almost Gogolian mirroring of sterile (but long-standing) monument and foreign "other," the bhagavats who recoil in horror, is in turn mirrored by a post-Komsomol group that calls itself Interknowledge (Interznanie, although the locals' nickname for the group is Isterzanie, torment; "Korabl' mira," 171).

The Australians' plan to "cleanse the miasma ..." is in turn mirrored by the post-Komsomol group's plan to stage an "action" or show entitled "Feast for the Soul," in Russian "Pir dukha," a homonymic expression that allows Lev and the Komsomol leader to share a laugh over bathroom humor-a form of Russian male bonding that supersedes any ideological, political, or commercial differences the two may have. In a parody of the post-Soviet estrada stage, "Pir dukha" features a "star of the Russian battlefields" singing at an open-air theater, surrounded by young people (heads shaven) who dance and clap. 
In tight, colored bicycle shorts, laced-up combat boots, and a camouflage bustier above her muscled abdomen, Anka-the-Machinegunner held the huge "penis of a microphone" near her red-like the rose of revolution-lips and sang:

Hey, once, and again!

He saved me from a bullet!

And who is right and who is not

Is known only to the Commissariat!

(“Korabl' mira," 173)

It is in this show that Lev finds inspiration to "save" his tourists. Concerned about his passengers, his ship, his employer, and the reputation of the firm paying his salary, Lev wants to avert what he senses is a potential "David Koresh-style" ending to their mission. All the swami's wordplay suddenly reveals itself to him: the impending "final dousing" involves a rope to avoid "pointless floating" - in other words, the "Great Dousing" is a mass-suicide plan, a battle plan against the "triumvirate of devils in the form of Chapaev" (“Korabl' mira," 175).

The Samara residents have taken the seriousness out of Soviet history by celebrating it in their ridiculous pop "Feast for the Soul," and Lev too backs the outsiders away from the horror of Soviet history by evoking the humor of Chapaev. In his final speech to the bhagavats, the new post-Soviet hero saves the day.

In order to do so, he calls to some of his own gods for inspiration and protection, and Aksyonov reveals the true meaning of "obnag": to convince the cult to abandon their suicide plan, Lev has to become utterly craven, "polnost'iu obnaglev", and he calls to "St. George (the patron saint of Moscow) . . . Fyodor Dostoevsky, Vasily Rozanov, and the young heroes of the revolution Leonid Kannegiesser and Fanny Kaplan.” Wishing he had a glass of Absolut, Lev begins his speech:

Your great and holy leader Shrila Prabhavishnu Swami with his eagle eye, inherited from a host of blessed incarnates, has seen directly into the essence of the Russian human landscape. This land was possessed by demons, and Vasily Ivanovich Chapaev was indeed the incarnation of Vritri, Madhu and Mur, who so unexpectedly revealed themselves in the bronze on the main square of Samara, formerly the city of Kuibyshev. However, the question is whether our steamer, this rusty barge, 
was a trap prepared for us by these powerful demons. It's not merely that the touring agency "Wandering Soul" offers its clients a bona fide guarantee of $100 \%$ cooperation; this goes much deeper.

The fact is that Chapaev himself-who was unquestionably a Fury of the Civil War, and was reflected later in demonic works in paper, cellulose, and bronze-over the years, that is to say about forty years after his own personal Final Dousing in the waters of the Ural, suddenly began to show signs of freedom from his demonic source, coming to life in an unending series of amusing anecdotes, with the help of which our barely alive people tried to free ourselves from the devils of communism. I will tell you a few of these little stories and you can judge for yourselves. ${ }^{41}$

Revisiting the river toponym and the traditional river crossing from countless Soviet war stories, Aksyonov also links Chapaev's watery death to the cult followers' planned "final dousing." Lev's speech is a summation of the militarized twentieth century and the meaning of Chapaev for that century.

As a finale to his tale, Aksyonov presents a third mirrored sculptural group that arrives post-Soviet style: mounted on the bed of a KAMAZ truck, the "Feast for the Soul" celebration rolls down the street, including Anka-theMachinegunner and Chapaev himself with a gladiolus in his hand instead of a saber. This bit of street theater is a way to demilitarize the military, and the gladiolus strikes the final blow. These are neither neo-Nazis nor flower children, but simply participants in a tasteless send-up of all that Soviet society claimed to hold sacred. ${ }^{42}$

On this basic level, Aksyonov's story is utterly straightforward: "outsiders" such as the Krishnaites can understand neither the heritage of the Russian Civil War nor the tragedy visited upon the Russian people by Soviet leaders, the Soviet economic system, and world history in the form of continual warfare throughout the twentieth century; and their attempts to "purify" the waters of Russia are laughable and over the top. Insiders too parody the cult of war and the heritage industry, but their sexualized ritual of public display in the end mocks the tragedy of the Russian twentieth century. ${ }^{43}$

41 Aksyonov, "Korabl' mira," 176.

42 Could this be a parody of present-day Samara-ites themselves, whose reputation is that they hold nothing sacred? See above.

43 Compare to the sexualized street "actions" of Iurii Mamin's 1990 film Bakenbardy (Sideburns). Aksyonov's Interznanie would fit right in with the "clubs" in that film; both texts parody provincial life, with its extreme and excessive reactions. 
The "Feast of the Soul" marks a ritual consumption of the self, a destructive sexual act that mocks the past and offers nothing for the future-except the laughter of Russian self-awareness and the bitter sense of irony that has enabled Russians to keep on. Lev tells Chapaev jokes to his clients, including one about cleanliness and hygiene:

Vasily Ivanovich and Petya go to a bathhouse. "Vasily Ivanovich," Petya exclaims, "you're so much dirtier than I am!"

"Well, of course," replies Chapaev, "I'm older than you."44

However, even in the midst of a ridiculous story about an exaggerated cult visiting Russia, Lev's Chapaev jokes represent something more serious: the "essence of Russia's process of struggling with the demon." ${ }^{45}$ Lev Obnag is no warrior and no ideal hero, but his is the attitude of a survivor: he finds his happiness in the ever-present Russian kolbasa, in beer and vodka and sex-and in the popular reinvention of the heritage industry that brought us the Chapaev anecdote. ${ }^{46}$

The "heritage industry" is scholar David Lowenthal's term. Lowenthal argues that "history tells all who will listen what has happened and how things came to be as they are. Heritage passes on exclusive myths of origin and continuance, endowing a select group with prestige and common purpose. . . . History is for all, heritage for ourselves alone." ${ }^{47}$ In the post-Soviet condition, history became compromised, and prestige and common purpose all but disappeared, leaving only the heritage industry with its empty symbols intact.

Lowenthal stresses that "to serve as a collective symbol heritage must be widely accepted by insiders, but inaccessible to outsiders. Its data are social,

44 Interestingly, in a novel in which he wants to "reclaim" the "real" Vasily Chapaev, Eduard Volodarsky permits himself this same joke. See Strasti po Chapaiu (St. Petersburg: Amfora, 2007), 220.

45 "Sut' demonoborcheskogo protsessa Rossii." "Korabl' mira," 177.

46 Graham argues that Chapaev jokes "liberate Chapaev from both the civil war chronotope in which he was 'crystallized' by Furmanov and the Vasil'evs and from the abstract epic of Soviet history." He continues, "The anekdot-al Vasilii Ivanovich is a positive cultural figure, a hero." See Resonant Dissonance, 112.

47 David Lowenthal, Possessed by the Past: The Heritage Crusade and the Spoils of History (New York: Free Press, 1996), 128. 
not scientific." ${ }^{48}$ Pelevin's novels Omon Ra and Chapaev and Pustota and Aksyonov's "The Ship of the World: Vasily Chapaev" explore these social data and the gap between insider and outsider access to Soviet heritage. In socialist realist texts (fiction, film, and sculpture), Chapaev represented a fulfillment of the spontaneity/consciousness dialectic, a "modern-day bogatyr," in John Haynes's words, forging a new Socialist life.

But if the indictment of Stalin's cult of personality, as Haynes has argued, "undermin[ed] the quasi-religious faith in leadership that constituted ... much of Chapaev's heroic status," ${ }^{49}$ then in postmodern post-Soviet texts, Chapaev is both hero and joke. Both a representation of the death and destruction that overwhelmingly filled the pages of history in the Soviet era and an example of the ability on the part of the Soviet/Russian people to rise above that tragedy. Both the marker of the epicenter of Russia's twentiethcentury topos of war and the negation of Stalin and his secret underground bunker through the tool of laughter. For writers at the end of the twentieth century, what's the difference?

The Chapaev monument in Samara was constructed by the German Russian sculptor Matvei Genrikhovich Manizer. This is the same sculptor who memorialized the partisans, sailors, and soldiers of the Revolution in statues that still grace the Moscow Metro. He also produced Stalin's death mask. ${ }^{50}$

His monument stands on Chapaev Square in today's Samara, marking the "epicenter" of Russia's twentieth-century problems. It stands on top of the secret underground bunker built for Stalin's use during World War II and thus unites the two wars that undergird Russia's self-identity in the twentieth century.

Stalin may have left the building, but Chapaev lives on.

48 David Lowenthal, "Identity, Heritage and History," in John R. Gillis, ed., Commemorations: The Politics of National Identity (Princeton: Princeton University Press, 1994), 49.

49 Haynes, New Soviet Man, 160, 164.

50 Manizer also helped train Ernst Neizvestny, the World War II veteran and sculptor who was exiled in the 1970s. His enormous Mask of Sorrow, installed at Magadan in 1996, commemorates the victims of Stalin's Kolyma camps. 